\title{
Why Are There No Universal Social Programs in the United States? \\ An Historical Institutionalist Comparison with Canada
}

\author{
Daniel Béland \\ University of Saskatchewan \\ Alex Waddan \\ University of Leicester
}

Much has been written about "American exceptionalism" in social policy but one aspect has received relatively little attention thus far: the absence of universal public social programs where entitlements to benefits and services are derived from citizenship or residency. This absence is especially striking because other liberal welfare regimes such as Canada and the United Kingdom have long developed such programs. Focusing on policy design and using Canada as a contrasting case, this article explains why there are no universal social programs in the United States, a country where the dichotomy between social assistance and social insurance dominates. The empirical analysis focuses on three policy areas: health, pensions, and family benefits. Stressing the impact of institutional factors on policy design, the article adopts an historical institutionalist approach and shows that the explanation for the absence of universal social programs varies from one policy area to the next.

Keywords: Social Policy, Welfare, Welfare State, Social Security, Social Insurance, Universal Social Programs, United States, Canada, Historical Institutionalism, Comparative Welfare Systems, Policy Design, American Exceptionalism.

\section{Spanish Abstract here}

Chinese Abstract here

In advanced industrial countries, universal social programming has remained a key social policy issue since the early post-war era (Marshall 1964). Although social insurance programs can effectively lead to universal coverage, this is distinct from the development of universal social programs that are typically funded from general tax revenues and offer social benefits and services to all citizens and, sometimes, permanent residents. Universal programs can also allocate cash benefits and social services to all members of a particular age-group (such as the elderly), or category of household (such as families with children), without any means or income test (Béland 
2010). Unsurprisingly, such universal programs are associated with the egalitarian social democratic welfare regime. Importantly, they are also present in a number of countries belonging to the liberal welfare regime (Esping-Andersen 1990). Thus, although private social benefits play a central role in the liberal regime, countries typically characterized as belonging to that regime, like Canada and the United Kingdom, have developed large universal programs over time (Anttonen, Häikiö, and Stefánsson 2012; Rice and Prince 2013). In fact, the implementation of the UK's National Health Service (NHS) in 1948 represented a milestone for the development of universal programs around the world (on the history of the NHS, see Webster 2002). Canada features universal programs in fields as different as family benefits, health care, and old-age pensions (Rice and Prince 2013; for a systematic discussion of the concept of universality as used in Canada, see Prince 2014).

The existence of universal programs in Canada and the UK points to what Rianne Mahon (2008) calls "varieties of liberalism," which explains how countries belonging to the liberal welfare regime can adopt policies that depart from the main logic of that regime, depending on the policy area and the historical moment. Yet, in contrast to Canada and the UK, the United States does not display a similar variety of policies since it has no large-scale, universal, social program. Instead, since the New Deal, the dichotomy between social insurance and social assistance has dominated U.S. social policy (Fraser and Gordon 1992), leaving little room for tax-financed universal programs. In this respect, the United States appears anomalous even within the context of the liberal welfare regime (Béland 2010). From this perspective, the long-standing debate about "American exceptionalism" in welfare state development takes on an additional dimension. Traditionally that debate has focused on scale and the question of whether the U.S. welfare state is significantly smaller than in other industrialized countries. Important recent research has 
suggested that the United States is less different in scale than a superficial examination suggests, with the difference being that much of what is in fact social welfare expenditure in the United States is "hidden" or "submerged" (Howard 2006; Mettler 2011). There has also been an important focus on private benefits; these may well be facilitated by public policy but they are quite distinct from direct public provision (Hacker 2002). The absence of universal social programs, however, is different again and the objective of this article is to examine this relatively neglected aspect of welfare state development in the United States, an aspect that establishes the country as distinct even within the liberal welfare regime. ${ }^{1}$

The purpose of this article is not to re-cast the United States as a welfare state laggard, which is a problematic perspective in any case (Amenta 1998). Our argument is not about the "meanness" or "generosity" of the American state. Instead, by adopting an historical and comparative approach coherent with the logic of American Political Development (Hacker 1998; Orren and Skowronek 2004), we aim to understand why the country has developed a variety of social policy programs - including some that are huge in scale — but not a large-scale universal program. This contribution follows the lead of John Myles (1998) in two different ways. First, the analysis focuses on what Myles (1998) calls "programmatic design" and, specifically in this case, the use of universal social programs as a type of policy instrument (Béland 2010). This emphasis on programmatic design distinguishes our work from the scholarship of authors like Nancy Fraser and Linda Gordon (1992), who explore what they see as the lack of social citizenship in the United States. Although universal programs are directly related to the issue of citizenship and the allocation of social rights, these rights are not necessarily only about universal programs. More

\footnotetext{
${ }^{1}$ Our analysis excludes primary and secondary public education, which is universal in both countries but does not belong to the welfare state in the strict sense of the term (Béland 2010).
} 
importantly, social citizenship is largely a normative issue that transcends, and is distinct from, the question we tackle in this article, which is the absence of a particular type of social program from the U.S. institutional landscape.

Second, once again following Myles (1998), we use Canada as a case to contrast with the United States. Though Canada is also a member of the liberal welfare regime, there is a further institutional logic in comparing the two countries: both feature a federal system and the extensive use of private social benefits (Boychuk and Banting 2008). Unlike the United States, however, Canada did develop large universal social programs during the post-war era, some of which survive today (Rice and Prince 2013). This article assesses how and why Canada has developed such universal programs in a relatively similar federal and liberal environment to provide a more systematic discussion of factors that may help explain why there are no universal programs in the United States.

\section{Policy Design and Universal Social Programming}

It is first necessary to define exactly what we mean by a universal social program. The starting point is simply the classic typology of social programs used by many students of social policy (e.g., Gøsta Esping-Andersen 1990; O’Connor 2002; Olsen 2002; Béland 2010; Rice and Prince 2013). Pointing to the variety of policy design in the modern welfare state, this typology is based partly on a discussion of three categories of program: social assistance, social insurance, and universal benefits and services. First, social assistance provisions are means-tested or incometested, and they are typically available to the poor, but not to better-off citizens. Second, social insurance programs create entitlements derived at least in part from one's contribution history. Finally, universal benefits and services are allocated to all citizens, permanent residents or, in the case of "demogrants," all members of a demographic group (e.g., older people or parents with 
young children). Consequently, these benefits and services differ from social assistance programs largely because of their eligibility criteria, while they are distinct from social insurance due to the lack of direct relationship between entitlements and contribution history (i.e., paying payroll taxes for a certain period of time in order to qualify for benefits). Thus, the distinction between the different types of program is defined in terms of funding, eligibility, and access: are programs funded through general taxation or social insurance taxes and who receives particular benefits or services and why? "Universal coverage," therefore, is not simply synonymous with far-reaching coverage. While the former requires the latter, the latter does not necessarily mean the former. This is a potentially crucial distinction because some social insurance programs can be near comprehensive, yet retain a contributory mechanism, which, in turn, has an impact on their ongoing institutional development.

We adopt an historical institutionalist approach that focuses on particular social programs and the set of institutional obstacles and opportunities that may shape their development over time (Orloff 1993; Pierson 1994; Maioni 1998). Well-known within the field of American Political Development (Compton 2014; Orren and Skowronek 2004), this perspective does not exclude the examination of ideological considerations surrounding universal benefits and services, but does suggest that there is not a simple, overarching answer to the question of why there are no universal social programs in the United States. There are themes that underlie U.S. social policy, but it is important to examine each policy outcome on its own terms. Though the end result may be that it is appropriate to think of the absence of universal social programs as a form of "American exceptionalism," that result is not predetermined. As we explain, policy development depended, at least in part, on contingent historical events. The value of this multi-layered style of analysis is reinforced by a comparative approach that starts with the examination of the Canadian case and 
explains how that country came to adopt a series of universal social programs. Importantly our study of Canada includes some analysis of efforts to dilute or eliminate key universal programs, which illustrates the uneven and potentially conditional nature of policy development.

The analysis focuses on three policy areas: health, pensions, and family benefits. The concentration on these areas is not an effort to cherry-pick the evidence. The United States has various social welfare programs in other areas, some of which, such as Supplemental Security Income (SSI) and Disability Insurance (DI), have grown significantly in recent years. But, like SSI, these are all either means-tested or, like DI and Unemployment Insurance, are founded on a contributory basis. Canada also has programs that are not universal in nature, such as the Canadian Pension Plan, but this reinforces our claim that it is typical for liberal regimes with a range of means-tested programs to nevertheless establish universal programs in some key areas.

In fact, choosing health, pensions, and family benefits constitutes cherry-picking the hard cases because these are the areas where the argument in favor of universal programs would seem to be the most compelling. The ill, the elderly, and families with young children seem to be the categories of people most likely to move political actors and policy makers to offer unconditional government support. In Canada, social policy did move toward universal programs in these areas, but in the United States it did not. At first glance, these consistently different outcomes make a sweeping, encompassing explanation appealing. One might, for example, turn to the notion of the "continental divide" (Lipset 1990), and the idea that the United States embraces economic individualism while Canada is more sympathetic to collectivist values. Yet, while this generalization clearly has some legitimacy, it does not fully explain policy developments. First, it carries the danger of being an explanation offered after the fact. Second, it potentially disregards 
key details about how events unfolded and disregards other explanations (Skocpol 1992; Steinmo and Watts 1995).

In this context, what this study illustrates is that an overarching explanation that simply says that the United States has a cultural allergy to universal programs is insufficient because policy developments in these three areas in the United States were distinct from one another. Importantly they were also distinct in Canada, where universal programs in the three policy areas did develop, but in a manner that reinforced the importance of a case-by-case analysis because they did so with varying degrees of political support and long-term resilience. This also explains why we have chosen an in-depth, two-country study rather than a broad cross-national survey. Our contention is that discrete factors affect policy development in each of our three policy areas. Hence, a systematic institutionalist focus, adopting a careful comparative perspective, provides a richness of insight.

\section{A Comparative Analysis}

According to the Organization for Economic Co-operation and Development (OECD), publicly funded social policy spending in 2009 consumed 19.2 percent of the GDP in both the US and Canada, compared to an OECD average of 22.1 percent. Private social spending accounted for 5.1 percent of the GDP in Canada and 10.6 percent of GDP in the United States, compared to an OECD average of 2.5 percent (OECD 2013). ${ }^{2}$ These raw numbers suggest that these two countries are correctly characterized as belonging to the same welfare regime, but this does not mean they

\footnotetext{
${ }^{2}$ Using direct social spending as a percentage of GDP is a flawed method of measuring aggregate welfare state effort as it misses spending that takes the form of "tax expenditures" (Howard 2006), but it remains a useful indicator of social policy trends within each nation-state and is perhaps especially useful with regard to universal programs that, by their nature, are likely to involve direct spending on cash or benefits rather than tax breaks and other targeted measures. It is also worth noting that the OECD average for public expenditure includes Mexico at 8.2 percent of GDP, South Korea at 9.4 percent, Chile at 11.3 percent, and Turkey at 12.8 percent.
} 
are identical. Major differences exist between these two countries in policy areas where, unlike the United States, Canada has a public system guaranteeing universal access for its citizens.

At a broader level, the social policy narrative in the two countries is an uneven one. In Canada, universality became a central feature of major social programs in the post-war era before being challenged from the 1980s onwards. Universalism's resilience varied from one policy domain to another. The United States, although known as a welfare state "laggard," in fact developed major welfare state programs in the mid-1930s, prior to the emergence of most staterun social welfare structures in Canada (Amenta 1998). Yet, while some of the programs established in the 1930s — notably the federal public pension system known as Social Security — have developed into comprehensive and highly popular programs often referred to as entitlements, these did not constitute policy universality in the strict sense of the term. So, while the United States does have large welfare state programs, these are either social insurance (seen as "earned" through specific contributions) or social assistance (means-tested "welfare" programs for the poor). This has left the United States as an outlier in some policy domains, most obviously with regard to health care but also family allowances.

To explain the specific differences between U.S. and Canadian social programs, we now turn to the fate of the benefits and services in our three policy areas, focusing on powerful institutional obstacles and opportunities that have shaped the politics of the welfare state, without disregarding ideological factors. Because of the federal nature of the two polities under investigation, the analysis takes policies adopted at both the national and the sub-state levels into account. This is especially true in Canada, a more decentralized and decentred polity (Théret 2002), where the ten provinces play the most crucial institutional role in large policy areas such as health care. 


\section{Canada}

Even compared to the United States, Canada in the first decades of the twentieth century appeared to be a social policy laggard, a situation that was directly related to the fragmented institutional nature of its federal system (Théret 2002). This early Canadian exceptionalism was especially true at the federal level, where it took until 1927 for Ottawa to enact major social policy legislation (military and civil service provisions excluded). The Old Age Pensions Act, as it was called, created an institutional framework for the enactment of federally subsidized old-age assistance pensions in the provinces (Bryden 1974; Orloff 1993). Then, in late 1935, the federal House of Commons passed the Employment and Social Insurance Act, which was much less comprehensive than the U.S. Social Security Act that had been signed by President Roosevelt earlier that year. In stark contrast to the omnibus nature of the U.S. legislation, Canadian policymakers focused simply on unemployment insurance. More importantly, and again in contrast to U.S. legislation that had survived court challenges, the Supreme Court of Canada and the UKbased Privy Council struck down the Employment and Social Insurance Act. There were, therefore, powerful institutional obstacles to federal social policy expansion before World War II, forcing Ottawa to negotiate a constitutional amendment with the provinces to make the 1941 implementation of a purely federal unemployment insurance scheme possible (Battle and Torjman 2001).

Starting in the mid-1940s, alongside social assistance and social insurance schemes, Canada developed universal programs across all three policy areas under consideration, but with varying degrees of generosity and, as it transpired, different levels of institutional resilience (for a comparative perspective see Béland et al. 2014). 
First, in the favorable institutional context of wartime, a Family Allowance program was implemented in 1945, making benefits available to all families with young children. Nationalist politicians in the province of Québec opposed the program, largely because they saw it as an invasion of provincial jurisdiction and an attack on French-Canadian families (at first, the program penalized large families, which were more common in Catholic Québec than in other provinces). In the end, however, this universal program became widely popular across the country, including in Québec (Marshall 1994; Béland and Lecours 2008). Financed through general revenues, this purely federal program was grounded in the Keynesian logic that came to dominate Canadian political economy in the 1940s. As Ken Battle and Sherri Torjman (2001, 16-17) put it, the main purpose "was to recognize the extra costs related to child rearing and to bolster the post-war economy by regularly putting cash into the hands of consumers-especially mothers." This time Ottawa did not need or seek provincial approval to implement this new, universal social program, and the expansion of the federal government's fiscal power during the war meant the federal government could finance it.

Illustrating that the wartime environment had not eliminated potential institutional obstacles to the expansion of the federal welfare state, the next federal universal social program, a purely federal flat pension known as Old Age Security (OAS), was not enacted until 1951, and not without intense constitutional bargaining between the central government and the provinces. The OAS offered a modest flat pension to all people aged 70 and older who met basic residency requirements. The flat pension later became available to people over 65. At the same time, the complex tax scheme initially created to finance benefits was replaced by general revenue funding (Béland and Myles 2005). Earlier on, in the late 1950s and early 1960s, when it became clear OAS could not provide adequate retirement income to all Canadians, federal policymakers rejected the 
option of dramatically expanding it (Babich and Béland 2009). This illustrates that policy development was subject to a changing political and institutional context. As a result, subsequent expansions of the public pensions system in Canada in the mid-1960s involved the creation of the Canada and Québec Pension Plans (CPP/QPP), a social insurance scheme financed through payroll contributions, and the Guaranteed Income Supplement (GIS), a social assistance program offering tax-funded, income-tested benefits to low-income seniors.

On the other hand, precisely as OAS was becoming only one element among others in the public pension system, Canada was in the process of adopting and implementing a universal health care system known as Medicare (which operates according to a different institutional logic than, and has little in common with, U.S. Medicare). The construction of this universalistic system began in Western provinces such as Saskatchewan, which established hospital insurance coverage in the late 1940s. Other provinces and then, in 1957, the federal government followed their example (Marchildon 2014). In 1962, Saskatchewan enacted the first universal provincial medical system. Four years later, Ottawa bowed to provincial pressure and enacted the Medical Care Act, which implemented federal funding for provincial health care systems. This legislation helped bring about universal coverage in all provinces (Hacker 1998; Maioni 1998; Théret 2002; Boychuk 2008).

Institutional factors largely explain why Canada adopted universal health care in the postwar era system while the United States failed to do so (Maioni 1998). The most central fact at hand here is the distinct nature of the Canadian party system and the existence of the Co-operative Commonwealth Federation (CCF, later replaced by the New Democratic Party [NDP]), a socialist party that governed Saskatchewan from 1944 to 1964. As Antonia Maioni (1998) demonstrated, in the field of health care, the conjunction of CCF-NDP mobilization in favor of universal health 
coverage and strong provincial pressure on Ottawa to provide funding help explain why Canada gradually departed from the U.S. path in the 1950s and 1960s.

Once Canada embraced a universal health care system, it became a core component of social citizenship, as well as a symbol of national identity. This is especially significant because it allows Canada to distinguish itself from the United States (Boychuk 2008; Béland and Lecours 2009; Brodie, 2002). This may partly explain why, as a universal yet decentralized system of social programming, Medicare has emerged as a true sacred cow in Canadian federal and provincial politics; direct attacks against universality are seldom tolerated. These remarks should not hide the sharp decline in federal funding for Medicare since 1977, when block grants replaced 50-50 matching funds (Rice and Prince 2013). In this context, universal provincial health care systems face strong pressures to "bend the cost curve" amidst growing health care spending (Marchildon and Di Matteo 2014).

This last point illustrates the challenges to universal programs in Canada since the late 1970s. Such challenges have had a more direct impact in the areas of family benefits and old-age pensions than in health care. First, Canada witnessed the actual phasing out of universal family allowances in the late 1980s (Rice and Prince 2013). Meanwhile, the federal government expanded the income-tested child tax credit, which had been created in the 1970s. In 1993, an income-tested Child Tax Benefit replaced Family Allowances and other benefits. Four years later, the Child Tax Benefit became the Canada Child Tax Benefit (Battle and Torjman 2001, 32). These reforms appeared as a clear and explicit rejection of the universalistic creed that had been associated with the Family Allowance demogrant since its enactment in 1944 (Rice and Prince 2013). Yet in 2006, the Harper Conservatives temporarily reversed this trend and enacted a new universal social program, the Universal Child Care Benefit (UCCB), a taxable flat benefit of \$100 CDN per month 
per child under six to all Canadian families (Prince and Teghstsoonian 2007; Mahon 2008; the Harper government announced a major expansion of UCCB benefits beginning in July 2015). A Conservative alternative to the childcare framework proposed by the previous Liberal government of Paul Martin and inspired by the subsidized childcare system in place in Québec since the late 1990s (Béland and Lecours 2008), UCCB was a conservative-friendly (i.e., pro-“family values”) measure because stay-at-home parents are entitled to receive it, even if they do not need or use child care facilities. The Trudeau Liberal government (2015-) recently abolished UCCB and two other programs (Canada Child Tax Benefit and National Child Benefit Supplement), replacing them with the tax-free and income-related Canada Child Benefit (CCB), which deprives higherincome earners from benefits, signaling the formal end of universality.

Second, attempts to curtail universality in the field of old-age pensions proved much less successful from both a political and a policy standpoint. Politically, an attempt to partially deindex OAS benefits in the mid-1980s backfired against the Mulroney Progressive-Conservative government. Facing strong popular protest, the Prime Minister was humiliatingly forced to withdraw his controversial proposal. Then, in 1989, to control OAS spending in an era of enduring fiscal constraints, the Mulroney government enacted a low-profile fiscal claw back that took away benefits allocated to wealthier Canadians through the personal income tax system. Initially affecting only a very small percentage of retirees, the claw back was designed to expand over time (Battle 1990). During the Chrétien years (1993-2003), however, the Liberal plan to replace OAS and GIS by an income-related scheme known as the Seniors Benefit was abandoned due to a clear lack of support from either the left or the right. In the end, formal universality survives despite the claw back, and OAS remains a widely popular program at the foundation of the Canadian public 
pension system (Béland and Myles 2005). ${ }^{3}$ Overall, and in strong contrast with the situation prevailing in the United States, Canada currently still operates universal social programs in two of the three policy areas under investigation

\section{United States}

According to the programmatic definition used in this article, the United States has no nationallyadministered universal programs. The welfare state programs that have federal funding are a mix of social insurance and social assistance arrangements. A sharp distinction exists between these two types of program, with the former regarded very much as the upper tier of provision and the latter as a lower tier (Fraser and Gordon 1992). In institutional and political terms, social insurance programs are seen as considerably more resilient than social assistance benefits, which seem more vulnerable to downsizing (Skocpol 1990a; for a critical assessment, see Howard 2006). This division is clear in the strong political and ideological contrast between the ever-popular Social Security system, a social insurance program that primarily delivers benefits to seniors, and the vilified and now defunct social assistance program, Aid to Families with Dependent Children (AFDC), which largely paid out cash benefits to low-income single parent families. The strength of Social Security and its resistance to reform efforts that would significantly undermine its level of social protection (Béland 2007), compared to the unpopularity of AFDC (Weaver 2000; Waddan 2003), illustrates the institutional and ideological dichotomy ever present in the United States. Importantly, there are social assistance programs like Medicaid and the Earned Income Tax Credit that do not suffer from the stigma traditionally attached to "welfare" (Grogan and Patashnik

\footnotetext{
3 This reality did not prevent Harper's Conservative government from announcing a gradual increase in eligibility age for the OAS and GIS, which should rise from 65 to 67 between 2023 and 2029 (Government of Canada 2012). This move is similar to the one witnessed in the United States in the aftermath of the 1983 decision to increase regular retirement age for Social Security from 65 to 67 between 2000 and 2027 (Pierson and Weaver 1993; Light 1995). The Trudeau government (2015-) recently cancelled the Conservative's plan to increase eligibility age for OAS and GIS.
} 
2005; Howard 2006). These, however, remain income-tested, thus reinforcing the institutionallyembedded dichotomy between insurance and assistance (Steensland 2008).

The United States is not unique in having a mix of insurance and assistance programs, but the fact that the United States does not have universal public social programs, which might be seen as corresponding to the third-leg of the welfare state's supportive stool, is distinct. Nevertheless, the country has developed extensive welfare state programs, most notably the hugely popular Social Security pension program. Republicans have periodically launched efforts to downsize or privatize this program but have been defeated in those efforts as Democrats successfully portray their opponents as an enemy of Social Security (Ross 2007; Béland and Waddan 2012a). Hence, the program has become referred to as "the third rail of American politics."

From an institutional standpoint, Social Security's popular support is derived at least to some degree from its near comprehensive coverage. In 2010, "88 percent of married couples and 85 percent of nonmarried persons aged 65 or older" received benefit payments (U.S. Social Security Administration 2013, 9) ${ }^{4}$ and it lifted 14.5 million elderly Americans above the official poverty level in 2011 (Van de Water and Sherman 2012). ${ }^{5}$ The contributory element for individuals (and their relatives) to qualify for benefits is complex but is in fact relatively undemanding. Furthermore, while Social Security benefits are based on previous earnings, unlike the Canadian OAS that is paid at a flat rate, the program is somewhat redistributive inasmuch as the benefits replace a higher proportion of pre-retirement income for lower income workers than for higher income workers (Dobelstein 2009, 98).

\footnotetext{
${ }^{4}$ This article confines its discussion to the elements of the Social Security program that provide benefits to retired workers and their surviving family. The full Old Age, Survivors, and Disability Insurance program covers many other beneficiaries (for a full discussion, see Dobelstein 2009).

${ }^{5}$ This refers to the U.S government's definition of poverty and should not be used as a comparative measure.
} 
It is therefore not unreasonable to look at the program today and mistake it for a universal scheme, but it is worth tracing the history and development of Social Security briefly in order to understand why social insurance, rather than universality, underpins the program. Despite the fact that some political actors pushed for the creation of a flat (universal) old-age pension to replace Social Security in the 1940s and early 1950s (Cates 1983), the public pension system created during the New Deal emerged as strongly grounded in a strict ideological and institutional dichotomy between social assistance and social insurance (see Fraser and Gordon 1992). This dichotomy was related to President Franklin Delano Roosevelt's belief that social insurance payroll contributions were necessary to protect social programs against political attacks. From this perspective, social insurance programs would generate "earned rights" that would make it harder for future politicians to dismantle. Enacted as part of the 1935 Social Security Act, old-age insurance explicitly represented a social insurance program grounded in a strict actuarial logic tying contributions to pension benefits. Although this actuarial logic began to weaken as early as the enactment of the 1939 amendments to the Social Security Act, a powerful discourse about "earned rights" emerged in the United States (Derthick 1979; Cates 1983; Béland 2007). In addition, while Social Security benefits are now widely distributed, the near comprehensive coverage was not part of the 1935 legislation; at the time about half of the workforce was excluded from participation (DeWitt 2010). There is not space here to investigate further why this was the case, but it illustrates that the program was never conceived as being one based on universalistic principles. ${ }^{6}$ Thus, even though Social Security now has near comprehensive coverage, its funding

\footnotetext{
${ }^{6}$ One particularly contentious argument concerns whether the 1935 Social Security Act reflected race bias since many of those workers excluded from participation were African-American. Scholars such as King and Smith (2005) have stressed the continuing importance of political cleavages over race issues in U.S. political life. More specifically with regard to the 1935 Act, Gordon (1994) and Lieberman (1998) have emphasized the importance of Southern congressional influence that pushed the law in a race-conscious
} 
mechanism means that it has a different institutional logic than a state-based pension funded out of general tax revenues. The case of pension policy simultaneously illustrates that the United States does not have a unique, inherent, aversion to big, encompassing, welfare state programs that offer widespread social protection, while emphasizing the importance of carefully understanding program development to explain why Social Security is nevertheless distinct from the Canadian OAS.

If there are important differences between the Canadian and U.S. pension schemes, then the practical and conceptual gap only grows when looking at family or child benefits and health care arrangements. Unlike Canada, the United States has never developed a federal family or child allowance program but, in the context of this article, it is valuable to reflect on the fate of AFDC, established as part of the 1935 Social Security Act, which paid out benefits to poor, mostly singleparent families with children. AFDC never had strong popular legitimacy and, as the number of recipients increased in the 1960s and 1970s, it became the source of much controversy. This was especially true as a combination of rule changes and court judgments that repudiated previous discriminatory practices meant that an increasing number of African American families gained eligibility to the program (Teles 1996; DeParle 2004). Perhaps counter-intuitively, the most important reform attempt in that period, initiated by Republican president Richard Nixon, would have introduced a guaranteed minimum income for American families. Nixon's proposal, the Family Assistance Plan, was not generous in promising an income of $\$ 1,600$ per annum to a family of four, and it was to be income-tested rather than universal, but in hindsight it would have potentially shifted the parameters of the U.S. welfare state (Moynihan 1973; Steensland 2008).

direction. That view has been countered by Davies and Derthick (1997) and DeWitt (2010), who argue that other factors better explain why the Act took the shape it did. 
But while it passed the House of Representatives, it failed in the Senate, emphasizing the importance of the country's fragmented institutional structures. Subsequent debate about AFDC cast doubt on the merit of paying any cash to even the poorest families with an able-bodied, working-aged, adult present. Urged on by conservative writers such as George Gilder (1981) and Charles Murray (1984), Republican political actors declared dependency on benefits rather than cash poverty to be the fundamental problem; an increasing number of Democrats, influenced by more moderate analysts such as David Ellwood (1988), accepted much of this argument.

Democratic presidential candidate Bill Clinton's 1992 promise to end “welfare as we know it" (Weaver 2000) is one example of this trend. Clinton's own reform effort in 1994 never gained legislative traction, but the momentum behind change was reinforced when the Republicans took control of Congress following the 1994 mid-term elections. Finally, in the summer of 1996, AFDC was abolished and replaced by the Temporary Assistance for Needy Families (TANF) program, which imposed strict time limits on most beneficiaries (Weaver 2000). It is, of course, impossible to know whether a benefit distributed more widely on a non-income-tested basis to families who had children, to reflect the increase in expenses such families incur, would have generated more popular support than AFDC, but that was never raised as an alternative. The principle of the Negative Income Tax underpinning Nixon's reform plan did in fact make something of a comeback in the form of the Earned Income Tax Credit (EITC) (Myles and Pierson 1997). The EITC refunds taxes to low-income families, including paying back more than a family's tax liability, and has become increasingly generous over time. The program has gained bi-partisan support and does effectively boost the finances of some poor families (Center on Budget and Policy Priorities 2016). But whereas Nixon's proposal offered a minimum income to all families, the EITC is only available to those with an earned income. 
Hence, although universal family benefits in Canada have proved potentially vulnerable to retrenchment, direct cash family assistance programs in the United States have always been income-tested and unpopular, offering minimal levels of social protection. Since 1996, while the EITC has expanded, public debate about the merits of paying direct cash benefits to families with children has not resurfaced in the mainstream federal social policy agenda. In contrast, arguments over health care provision have been a constant feature of U.S. political life over recent years, reflecting the fact that the country is the only one in the developed world that leaves a significant part of its population without health insurance coverage while, simultaneously, spending a higher proportion of GDP on health care than any other country (Kaiser Family Foundation 2010; OECD 2010).

There has been considerable scholarly disagreement about why the U.S. health care system developed in this unique fashion, with private funding at the heart of the system, and why proposals for publicly guaranteed universal coverage are regularly defeated (cf. Jacobs 1993; Steinmo and Watts 1995; Hacker 2002; Boychuk 2008). From an institutionalist perspective, in the mirror of the Canadian experience, it is clear that the lack of a genuine labor party similar to the CFF-NDP (Maioni 1998), the vested nature of private health insurance (Hacker 2002), as well as the fragmentation of political power at the federal level, which empowers such vested interests (Steinmo and Watts 1995), make it harder for U.S. advocates of universal health coverage to secure political support for their legislative proposals than for their Canadian counterparts.

Largely to offset such institutional obstacles, from the 1950s onwards, these policy advocates moved from promoting a comprehensive government-run program towards finding ways of providing support for people who found it difficult to get health insurance in the private sector. This approach paid some dividends in the mid-1960s with the enactment of the Medicare 
and Medicaid programs, which covered the elderly and some of the poorest Americans, respectively (Marmor 2000). Yet even this moment of triumph for reformers repeated the dichotomy between social insurance and social assistance in U.S. social policy: Medicare was created as a federal social insurance program and Medicaid was created as a joint federal-state social assistance program that was income-tested and included considerable state-level discretion about who would be covered and what they would be covered for. Hence Medicare, funded largely by premiums and a compulsory payroll tax, belonged to the upper tier of U.S. welfare state programs, while Medicaid, funded by a mix of federal and state monies from general revenues, was "welfare medicine."

In reality, from an institutionalist lens, these basic remarks do not properly describe the two programs. The Medicare payroll tax in fact only partially funds one part of the Medicare program, which also relies on beneficiaries paying premiums and drawing funds from general revenues (see Oberlander 2003; Moon 2006.) Furthermore, Medicaid defied the notion that income-tested programs are unpopular and cannot grow; through the 1980s and 1990s, a series of incremental reforms did expand the recipient base (Olson 2010). Nevertheless, neither of the programs can be described as universal. Most obviously, Medicaid remains income-tested and Medicare is underpinned by payroll contributions that cover one major aspect of provision (Part A) and an optional premium that covers a separate set of medical costs (Part B). Moreover, Medicare is not comprehensive; there are a variety of deductibles and co-payments, as well as annual limits on certain types of treatment, meaning that many seniors face significant out-ofpocket expenses (Moon 2006, 22-3).

In some ways, the development and expansion of Medicare and Medicaid legitimized and helped reproduce the institutionally-dominant position of the private sector in American medicine 
as it meant that private insurers were, to some extent, relieved of covering the elderly and the poor, who are two high-risk groups in terms of likely demand for health care services.

After decades of debates about how to reform the U.S. health care system, the 2010 Patient Protection and Affordable Care Act (PPACA) became the most important health care reform since the mid-1960s. Because of the strength of the institutional legacies created during the post-war era, however, this landmark legislation does not challenge the dominance of private insurance provision in the U.S. health care system. Due to the institutional fragmentation of power in Washington and the high number of veto points in Congress, multiple compromises proved necessary to enact the PPACA, which weakened it. For instance, institutionally driven compromise led to the abandonment of the "public option" (an approach according to which the federal government would have competed directly against private insurers on the market) supported by the left of the Democratic Party but unable to muster sufficient support among Democrats in Congress (Béland and Waddan 2012b).

Despite such compromises, the Congressional Budget Office (CBO) predicted at the time of passage that the PPACA would insure an extra 32 million Americans by 2019 (CBO 2010). This was to be achieved in two main ways. First, the creation of health insurance exchanges at the state level that would offer low insurance packages to low-income households (up to incomes of 400 percent of the federal poverty level), with those households receiving a subsidy to cover their costs. Second, the PPACA effectively said that the Medicaid program would be expanded to cover everyone with an income up to 133 percent of the poverty level.

In addition, the PPACA imposed a mandate on individuals to buy insurance when they could afford to do so and introduced new rules about which people private insurers could or, more significantly, could not drop from their rolls. Taken together, these last measures constitute a 
government-imposed collectivization of risk on the private insurance market. In aggregate, especially given that the reforms were to be funded by a series of increased taxes and fees on medical providers and high earners, it is fair to describe the PPACA as "a landmark in U.S. public social provision" that "draws resources from the privileged to spread access to affordable health insurance to most of the U.S. citizenry" (Jacobs and Skopol 2011, 83). Yet, for all this, the PPACA far from "socializes" U.S. medicine. The PPACA still left the United States as the only country in the industrialized world with a substantial portion of its population lacking health care coverage (Marmor and Oberlander 2010). This was exacerbated in the summer of 2012 when the third institution of the federal government, the Supreme Court, diluted the likely impact of the Medicaid expansion by ruling that the federal government had overstepped its authority by effectively imposing expansion on the states, thus empowering state governments that did not wish to cooperate in the implementation of the PPACA (Béland, Rocco, and Waddan 2016). Thus, even in a context of a Democrat President and significant Democrat majorities in both chambers of Congress, embedded policy legacies, in the form of the existing employer-based system, combined with still relevant party fragmentation, which effectively gave each Democrat senator veto power. This meant that proposals for a single-payer health care system, similar to the Canadian model, gained little traction.

\section{Discussion}

This analysis of three core social policy areas in Canada and the United States shows that, although both countries belong to the liberal welfare regime (Esping-Andersen 1990), they exhibit distinctive patterns of welfare state development with regard to their respective adoption of universal social programs. While the United States has developed substantive welfare state programs, none can be described as genuinely universal, as the OAS public pension or the 
Medicare health system in Canada are. Furthermore, while the universality of family allowances in Canada has been eroded since the program was initially established in the mid-1940s, the United States has never seen an equivalent scheme.

On the other hand, there has been policy activity in these areas that casts interesting light on U.S. social policy programs and why the U.S. welfare state has not embraced universal social programs. As discussed above, social welfare programs in the United States are perceived as embodying the principles of either insurance or assistance. This may be empirically misleading inasmuch as the contributions people make through dedicated payroll taxes do not match what they receive in benefits, especially in the case of Medicare, but it remains a politically vital institutional distinction. This strong opposition between social assistance and social insurance helps explain the absence of a genuine sense of social citizenship in the United States (Fraser and Gordon 1992; Myles 1997). The demise of AFDC, which provided some cash aid to a particular sub-set of poor families with children and was replaced by Temporary Assistance to Needy Families in 1996, is a sharp reminder of how even the most economically vulnerable people in the United States can be expected to support themselves. Yet it is important to acknowledge how the institutional logic of "earned entitlements" has provided the relevant programs, especially Social Security, with an extra layer of defense against retrenchment. Political actors in Canada have looked to cut back on the general revenue funding for universal programs with varying degrees of success. In the United States, on the other hand, the institutionally embedded sense that beneficiaries have paid for their benefits has deterred direct, large-scale cutbacks to Social Security (Pierson 1994; Béland and Waddan 2012a). In this context, it is important to note that universalism should not be conflated with either popularity or institutional resilience. Furthermore, the case of Social Security illustrates that for all the anti-big government rhetoric, ever present in conservative 
circles of American public life, there is a big government program that is popular and resistant to retrenchment, suggesting the limitations of a sweeping cultural explanation of U.S. welfare state development.

Perhaps the most obvious institutional difference between these two neighbors is seen in respect to their health care systems. The Canadian Medicare system guarantees governmentfunded health care for all Canadians. In contrast, the United States has allowed a situation to continue where many millions of its citizens and residents live with the knowledge that ill health could also lead to economic insecurity. If fully implemented, the PPACA will significantly reduce the inequities that have developed by providing health insurance to many uninsured Americans, but the Obama administration rejected the option of pursuing a single-payer style program that would have emulated the Canadian model and put government financing at the heart of guaranteeing Americans access to health care.

Explaining these differences and answering why there are no universal social programs in the United States, in contrast to Canada and other countries that conform to the liberal social welfare regime type, requires a study and appreciation of the role of institutional factors. Yet it is important to break down these factors and look at how they interacted with other forces in each of the three policy areas at hand, and in contrast with what happened in Canada. First, in the field of old-age pensions, the 1935 federal decision to opt for social insurance created an institutional path that proved harder and harder to break over time, as Social Security created powerful constituencies, both within and outside government (Derthick 1979; Pierson 1994). If the federal government had adopted a smaller-scale version of the universal Townsend Plan advocated in the mid-to-late-1930s (Amenta 2006), the history of pension reform in the United States could have taken a different, universal path. The Canadian case illustrates what this alternative path could 
have looked like. On one hand, the first national public pension framework adopted in Canada was not a social insurance programs but a social assistance scheme co-financed by the federal government and the provinces. From an institutional perspective, it is much easier to move from a social assistance program to a universal program, which is exactly what Canada did in 1951. Social insurance pension programs are especially resilient and hard to reform (Myles and Pierson 2001), and the story of Social Security in the United States shows how proponents of universal flat pensions failed miserably when they attempted to make a case for their policy alternative (Derthick 1979; Cates 1982).

Second, in the field of family benefits, the United States adopted a social assistance logic long before the New Deal (Skocpol 1992) and no attempt was ever made to break from that institutional logic, either during or after the New Deal. Two factors may have reinforced this institutional logic. On one hand, racism in the South created strong pressures in Congress to preserve state control over social assistance family benefits, which constituted powerful tools of social and economic control in the hands of the white elite (Quadagno 1994). Furthermore, as the AFDC rolls expanded from the 1960s onwards as a result of the Courts' undermining of state-level discretion to bar people from the program (Teles 1996), there is evidence that the image of the African American "welfare queen" served to foster prejudice against the program and its recipients (Gilens 1999). On the other hand, in contrast to the situation prevailing in other countries, the United States did not witness a bold push for family allowances to increase fertility, as was the case in France in the early 1930s (Messu 1992), or to favor macro-economic stabilization, as in Canada in the mid-1940s (Jean 1986). In the second country, the push materialized during World War II and led directly to the implementation of family allowances in 1945 (Jean 1986). 
Third, in the field of health care, the post-war popularity of Social Security and its promotion by federal officials and constituencies outside government, such as the labor movement, transformed the program into a social insurance template for what would become Medicare, which remains the largest public health care program in the United States. Simultaneously, Medicaid first emerged as a modest program but gradually grew to become a central aspect of the U.S. health care system, a situation reinforced with the recent adoption of the PPACA, which features the expansion of this social assistance program. Considering this, the dichotomy between social insurance and social assistance is central to U.S. public health care more than ever before, as most workers continue to depend on voluntary, private insurance coverage in the context of a highly fragmented system. This fragmentation contrasts strongly with the relatively simplicity of the single-payer, health care system present in each Canadian province. The private sector only plays a strong role in areas such as dentistry and, especially, drug coverage (Boothe 2015). As suggested above, intergovernmental pressures and the presence of the CCF and later the NDP explain why Canada was able to develop a large, universal public health care system during the post-war era, thereby taking a very different (universalistic) institutional path from the United States (Maioni 1998).

An alternative to our institutionalist and programmatic approach would have focused on the overall influence of one all-encompassing factor like "class" or "national values" to explain the absence of universal welfare state programs in the United States. Following Theda Skocpol (1990b), however, we argue that this type of simple, catch-all explanation is simply too broad and general to account for what are in fact highly specific and contingent historical and policy developments. As for the key role of private benefits, which help explain the more limited development of public programs in the United States, alone they cannot account for the lack of 
universal programming simply because Canada has also relied on private health and pension benefits, which has not prevented the advent of large universal social policies in that country (Boychuk and Banting 2008). Finally, although we suggested that race played a role in the United States, it is clear that this factor only matters in particular institutional contexts that mediate its impact, a claim that is consistent with our careful and detailed analysis of concrete policy areas over time (Lieberman 2002). Our comparative analysis of three policy areas moves beyond general claims and combines particular types of explanation (Parsons 2007) that might not be as elegant as broad generalizations about class or national values, but are probably more precise and insightful from an empirical standpoint.

\section{Conclusion}

This article explored a key yet neglected aspect of the debate on "American Exceptionalism" by addressing the question of why there are no universal social programs in the United States. We analyzed three policy areas (old-age pensions, family benefits, and health care) in the United States and Canada. Canada is an appropriate point of comparison since it also belongs to the liberal welfare regime and also features a federal system, but has, unlike the United States, developed universal programs in these three areas.

What our comparative analysis suggests is that the explanation for why no universal programs emerged in the United States varies among these three policy areas. Although the article emphasizes the role of institutional factors in all three areas, it spells out which of these factors actually made a difference in each policy area, and how such factors might have combined with other forces, such as race (in the case of AFDC) and the role of ideas (in the case of the push for social insurance), to produce a particular outcome, in our case the lack of universal social programs 
in the United States. The addition of Canada as a contrasting case enriched the analysis considerably, as it suggests some of the factors that helped bring about universal social programs in a different federal and liberal country in the Americas.

For U.S. policymakers and policy practitioners, turning to Canada can also provide useful insight into how universal programs become possible and manageable in the first place in a promarket North American society. For instance, in the field of health care, looking at Canada could help American policymakers design a decentralized yet universal healthcare system. This could be achieved, in part, through a further expansion of Medicaid, a program that is run by the states, which is a similarity with Canadian Medicare, a system that is operated by the provinces, with fiscal support from the federal government. This is only one of the areas in which Canada-U.S. comparisons can prove insightful for health care policy experts (for other examples see Maioni and Marmor, 2008). Beyond health care, U.S. policy practitioners can learn a great deal from Canada in the field of pension reform. This is the case because the Canadian public pension system, which is based on a complementary relationship between universal, earnings-related, and incometested programs, is much more effective than its U.S. counterpart in reducing poverty among older people (Wiseman and Yčas, 2008). A key aspect of this success is GIS, an income-related program that provides additional support for recipients of the universal OAS pension on an income-tested basis that contrast with the means-tested and less generous SSI benefits for seniors. Although offering better, income-tested protection to older people in the United States would increase costs for the federal government, Canada provides a successful example of a targeted program that can work hand-in-hand with universal and social insurance programs to effectively fight poverty (Wiseman and Yčas, 2008). Interestingly, what is important in this case is not so much universality but how a universal program like OAS can work in tandem with a social assistance programs like 
GIS to effectively fight poverty and improve social protection. This is an important lesson for the analysis of universal programs, which do not exist in a vacuum but in a changing institutional context. As illustrated by the comparison between the United States and Canada in this article, understanding how programs in different policy domains evolve and prove more susceptible or resilient to change as they mature, can be considerably enhanced by an appropriate comparative and historical perspective.

\begin{abstract}
About the Authors
Daniel Béland holds the Canada Research Chair in Public Policy (Tier 1) at the JohnsonShoyama Graduate School of Public Policy. A specialist of fiscal and social policy, he has published more than 15 books and 110 articles in peer-reviewed journals. His two most recent books are Advanced Introduction to Social Policy (Edward Elgar, 2016; with Rianne Mahon), and Obamacare Wars: Federalism, State Politics, and the Affordable Care Act (University Press of Kansas, 2016; with Philip Rocco and Alex Waddan).

Alex Waddan is an Associate Professor in Politics in the School of History, Politics and International Relations at the University of Leicester. He has published four books and numerous peer-reviewed journal articles. His most book is Obamacare Wars: Federalism, State Politics, and the Affordable Care Act (University Press of Kansas, 2016; with Daniel Béland and Philip Rocco)
\end{abstract}

\title{
References
}

Amenta, Edwin. 1998. Bold Relief: Institutional Politics and the Origins of Modern American Social Policy. Princeton: Princeton University.

. 2006. When Movements Matter: The Townsend Plan and the Rise of Social Security. Princeton: Princeton University Press.

Anttonen, Anneli, Liisa Häikiö, and Kolbeinn Stefánsson. 2012. Welfare State, Universalism and Diversity. Cheltenham: Edward Elgar Publishing.

Babich, Kristina, and Daniel Béland. 2009. "Policy Change and the Politics of Ideas: The Emergence of the Canada/Quebec Pension Plans." Canadian Review of Sociology 46 (3): 253-271. Accessed on April 25, 2017. Available online at http://onlinelibrary.wiley.com/doi/10.1111/j.1755-618X.2009.01214.x/abstract

Battle, Ken [under the pseudonym of Grattan Gray]. 1990. "Social Policy by Stealth," Policy Options, 11(2): 17-29. 
Battle, Ken, and Sherri Torjman. 2001. The Post-Welfare State in Canada: Income-Testing and Inclusion. Ottawa: Caledon Institute of Social Policy.

Béland, Daniel. 2007. Social Security: History and Politics from the New Deal to the Privatization Debate. Updated paperback edition. Lawrence: University Press of Kansas. . 2010. What is Social Policy? Understanding the Welfare State. Cambridge: Polity.

Béland, Daniel, and André Lecours. 2008. Nationalism and Social Policy: The Politics of Territorial Solidarity. Oxford: Oxford University Press.

. 2009. "Nationalism, Federalism, and Social Citizenship: The Continental Divide Revisited." In Dominant Nationalism, Dominant Ethnicity: Identity, Federalism and Democracy, edited by André Lecours and Genevieve Nootens. Brussels: Peter Lang. 131148.

Béland, Daniel, and John Myles. 2005. "Stasis amidst Change: Canadian Pension Reform in an Age of Retrenchment." In Ageing and Pension Reform around the World, edited by Giuliano Bonoli and Toshimitsu Shinkawa. Cheltenham: Edward Elgar. 252-272.

Béland, Daniel, and Alex Waddan. 2012a. The Politics of Policy Change: Welfare, Medicare and Social Security Reform in the United States. Washington, DC: Georgetown University Press.

. 2012b. "The Obama Presidency and Health Insurance Reform: Assessing Continuity and Change." Social Policy and Society 11 (3): 319-330. Accessed on April 25, 2017. Available online at https://www.cambridge.org/core/journals/social-policy-andsociety/article/obama-presidency-and-health-insurance-reform-assessing-continuity-andchange/7A3E1A45D03B44CE9B3836CFAC2BF30B

Béland, Daniel, Paula Blomqvist, Jørgen Goul Andersen, Joakim Palme and Alex Waddan. 2014.

"The Universal Decline of Universality? Social Policy Change in Canada, Denmark, Sweden and the UK", Social Policy and Administration, 48 (7): 739-756. Accessed on May $4^{\text {th }} 2017$. Available at http://onlinelibrary.wiley.com/doi/10.1111/spol.12064/full

Béland, Daniel, Philip Rocco and Alex Waddan. 2016. Obamacare Wars: Federalism, State Politics, and the Affordable Care Act. Lawrence: University Press of Kansas.

Boothe, Katherine. 2015. Ideas and the Pace of Change: National Pharmaceutical Insurance in Canada, Australia and the United Kingdon. Toronto: University of Toronto Press.

Boychuk, Gerard W. 2008. National Health Insurance in the United States and Canada: Race, Territory, and the Roots of Difference. Washington, DC: Georgetown University Press.

Boychuk, Gerard W., and Keith G. Banting. 2008. "The Canadian Paradox: The Public-Private Divide in Health Insurance and Pensions." In Public and Private Social Policy: Health and Pension Policies in a New Era, edited by Daniel Béland and Brian Gran. Basingstoke: Palgrave Macmillan. 92-122.

Brodie, Janine. 2002. "Citizenship and Solidarity: Reflections on the Canadian Way." Citizenship Studies 6: 377-394. 
Bryden, Kenneth. 1974. Old Age Pensions and Policy-Making in Canada. Montreal and Kingston: McGill-Queen's University Press.

Cates, Jerry R. 1983. Insuring Inequality: Administrative Leadership in Social Security, 1935-54. Ann Arbor: University of Michigan Press.

Center on Budget and Policy Priorities. 2016. Policy Basics: The Earned Income Tax Credit. Accessed on December 17, 2016. Available online at http://www.cbpp.org/research/federaltax/policy-basics-the-earned-income-tax-credit

Compton, John W. 2004. "American Political Development." In The Encyclopedia of Political Thought. Accessed on December 17, 2016. Available online at http://onlinelibrary.wiley.com/doi/10.1002/9781118474396.wbept0022/abstract/

Congressional Budget Office (CBO). 2010. H.R. 4872, Reconciliation Act of 2010. March 18. Accessed on December 17, 2016. Available at http://www.cbo.gov/ftpdocs/113xx/doc11355/hr4872.pdf

Davies, Gareth, and Martha Derthick. 1997. "Race and Social Welfare Policy: The Social Security Act of 1935." Political Science Quarterly 112 (2): 217-235. Accessed on April 25, 2017. Available online at https://www.jstor.org/stable/2657939

DeParle, Jason. 2004. American Dream: Three Women, Ten Kids and a Nation's Drive to End Welfare. New York: Penguin Books.

Derthick, Martha. 1979. Policymaking for Social Security. Washington, DC: Brookings Institution.

DeWitt, Larry. 2010. "The Decision to Exclude Agricultural and Domestic Workers from the 1935 Social Security Act.” Social Security Bulletin 70 (4): 49-68. Accessed on April 25, 2017. Available online at https://www.ssa.gov/policy/docs/ssb/v70n4/v70n4p49.html

Dobelstein, Andrew. 2009. Understanding the Social Security Act. New York: Oxford University Press.

Ellwood, David. 1988. Poor Support: Poverty in the American Family. New York: Basic Books.

Esping-Andersen. Gøsta. 1990. The Three Worlds of Welfare Capitalism. Cambridge: Polity.

Fraser, Nancy, and Linda Gordon. 1992. "Contract versus Charity: Why Is There No Social Citizenship in the United States?" Socialist Review 22 (July): 45-68.

Gilder, George. 1981. Wealth and Poverty. New York: Basic Books.

Gilens, Martin. 1999. Why Americans Hate Welfare: Race, Media and the Politics of Antipoverty Policy. Chicago: University of Chicago Press

Gordon, Linda. 1994. Pitied but Not Entitled: Single Mothers and the History of Welfare, 18901935. New York: Free Press

Government of Canada. 2012. Budget 2012. Ottawa: Government of Canada.

Grogan, Colleen, and Eric Patashnik. 2005. "Medicaid at the Crossroads." In Healthy Wealthy and Fair: Health Care and the Good Society, edited by James Morone and Lawrence Jacobs. New York: Oxford University Press. 267-296.

Hacker, Jacob S. 2002. The Divided Welfare State: The Battle over Public and Private Social Benefits in the United States. New York: Cambridge University Press. 
. 1998. "The Historical Logic of National Health Insurance: Structure and Sequence in the Development of British, Canadian, and U.S. Medical Policy." Studies in American Political Development 12 (1): 57-130. Accessed on April 25, 2017. Available online at https://www.cambridge.org/core/journals/studies-in-american-political-

development/article/the-historical-logic-of-national-health-insurance-structure-andsequence-in-the-development-of-british-canadian-and-us-medicalpolicy/9628CA28ACC5AF149F9CF38C1BD27D01

Howard, Christopher. 2006. The Welfare State Nobody Knows: Debunking Myths about U.S. Social Policy. Princeton: Princeton University Press.

Jacobs, Lawrence R. 1993. The Health of Nations: Public Opinion and the Making of Health Policy in the U.S. and Britain. Ithaca, NY: Cornell University Press.

Jacobs. Lawrence and Theda Skopol. 2011. "Hard-Fought Legacy: Obama, Congressional Democrats, and the Struggle for Comprehensive Health Care Reform" in Theda Skocpol and Lawrence Jacobs (eds.) Reaching for a New Deal: Ambitious Governance, Economic Meltdown, and Polarized Politics in Obama's First Two Years. New York: Russell Sage Foundation, pp. 53-104.

Jean, Dominique. 1986. “Les parents québécois et l'État canadien au début du programme des allocations familiales: 1944-1955." [Quebec Parents and the Canadian State at the Beginning of the Family Allowance Program: 1944-1955]. Revue d'histoire de l'Amérique française 40 (1): 73-95. Accessed on April 25, 2017. Available online at http://www.erudit.org/fr/revues/haf/1986-v40-n1-haf2342/304425ar/

Kaiser Family Foundation. 2010. Health Insurance Coverage of the Total Population, states. Accessed on December 17, 2016. Available online at: http://www.statehealthfacts.org/comparebar.jsp?ind=125\&cat $=3$

King, Desmond, and Rogers Smith. 2005. "Racial Orders in American Political Development." American Political Science Review 99 (1): 75-92. Accessed on April 25, 2017. Available online at https://www.cambridge.org/core/journals/american-political-sciencereview/article/racial-orders-in-american-politicaldevelopment/78C4115EFEB5159EAE76D558D7D86CCB

Lieberman, Robert C. 2002. "Ideas, Institutions, and Political Order: Explaining Political Change." American Political Science Review 96 (4): 697-712. Accessed on April 25, 2017. Available online at https://www.cambridge.org/core/journals/american-political-sciencereview/article/ideas-institutions-and-political-order-explaining-politicalchange/94D23A0A7B76C5D47160F8D980812C2F

. 1998. Shifting the Color Line: Race and the American Welfare State. Cambridge, MA: Harvard University Press

Light, Paul C. 1995. Still Artful Work: The Continuing Politics of Social Security Reform. New York: McGraw-Hill.

Lipset, Seymour Martin. 1990. Continental Divide: The Values and Institutions of the United States and Canada. New York: Routledge.

Mahon, Rianne. 2008. "Varieties of Liberalism: Canadian Social Policy from the 'Golden Age' to the Present." Social Policy \& Administration 42 (4): 342-361. Accessed on April 25, 2017. 
Available online at $\quad$ http://onlinelibrary.wiley.com/doi/10.1111/j.14679515.2008.00608.x/abstract

Maioni, Antonia. 1998. Parting at the Crossroads: The Emergence of Health Insurance in the United States and Canada. Princeton: Princeton University Press.

Maioni, Antonia and Theodore R. Marmor. 2008. Health Care in Crisis: The Drive for Health Reforms in Canada and the United States. Washington, DC: Woodrow Wilson International Center for Scholars. Accessed on April 25, 2017. Available online at https://www.wilsoncenter.org/sites/default/files/HealthCareinCrises_1i2v9.pdf

Marshall, Dominique. 1994. "Nationalisme et politiques sociales au Québec depuis 1867: Un siècle de rendez-vous manqués entre l'État, l'Église et les familles." [Nationalism and Social Policy in Quebec since 1867: A Century of Missed Opportunities between the State, the Church and Families]. ]. British Journal of Canadian Studies 9 (2): 301-347.

Marshall, T.H. 1964. Class Citizenship and Social Development. New York: Doubleday.

Marchildon, Gregory P. 2014. "The Three Dimensions of Universal Medicare in Canada." Canadian Public Policy 57 (3): 362-382. Accessed on April 25, 2017. Available online at

Marchildon, Gregory P., and Livio Di Matteo (eds.). 2014. Bending the Cost Curve in Health Care: Canada's Provinces in International Perspective. Toronto: University of Toronto Press.

Marmor, Theodore R. 2000. The Politics of Medicare. 2nd ed. New York: Aldine de Gruyter.

Marmor, Theodore R. and Jonathan Oberlander. 2010. "The Health Bill Explained at Last," New York Review of Books, August 19. Accessed on April 25, 2017. Available online at http://www.nybooks.com/articles/2010/08/19/health-bill-explained-last/

Messu, Michel. 1992. Les politiques familiales: du natalisme à la solidarité. [Family Policies: From Natalism to Solidarity]. Paris: Éditions de l'Atelier.

Mettler, Suzanne. 2011. The Submerged State: How Invisible Government Policies Undermine American Democracy. Chicago: University of Chicago Press.

Moon, Marilyn. 2006. Medicare: A Policy Primer. Washington, DC: The Urban Institute Press.

Moynihan, Daniel P. 1973. The Politics of a Guaranteed Income: The Nixon Administration and the Family Assistance Plan. New York: Random House.

Murray, Charles. 1984. Losing Ground: American Social Policy, 1950-1980. New York: Free Press.

Myles, John. 1998. "How to Design a 'Liberal' Welfare State: A Comparison of Canada and the United States." Social Policy \& Administration 32 (4): 341-364. Accessed on April 25, 2017. Available online at http://onlinelibrary.wiley.com/doi/10.1111/14679515.00120/abstract

. 1997. "Neither Rights nor Contracts: The New Means-Testing in the U.S. Aging Policy." In The Future of Age-Based Public Policy, edited by Robert B. Hudson. Baltimore: Johns Hopkins University Press. 46-55. 
Myles, John, and Paul Pierson. 1997. 'Friedman's Revenge: The Reform of 'Liberal' Welfare States in Canada and the United States." Politics and Society 25 (4): 443-72. Accessed on April 25, 2017. Available online at http://journals.sagepub.com/doi/abs/10.1177/0032329297025004004

. 2001. "The Comparative Political Economy of Pension Reform." In The New Politics of the Welfare State, edited by Paul Pierson. Oxford: Oxford University Press. 305-333.

Oberlander, Jonathan. 2003. The Political Life of Medicare. Chicago: University of Chicago Press.

O'Connor, Julia S. 2002. "Understanding the Welfare State and Welfare States: Theoretical Perspectives." In Political Sociology: Canadian Perspective, edited by Douglas Bear. Oxford: Oxford University Press. 110-128.

OECD. 2010. Directorate for Employment, Labour and Social Affairs. OECD Health Data for 2010. Accessed on December 17, 2016. Available online at http://www.oecd.org/document/16/0,3343,en_2649_34631_2085200_1_1_1_l, $00 . \mathrm{html}$ . 2013. Social Expenditure Database. Accessed on December 17, 2016.Available online at http://www.oecd.org/els/soc/socialexpendituredatabasesocx.htm

Olsen, Gregg. 2002. The Politics of the Welfare State: Canada, Sweden, and the United States. Toronto: Oxford University Press.

Orren, Karen, and Stephen Skowronek. 2004. The Search for American Political Development. New York: Cambridge University Press.

Orloff, Ann Shola. 1993. The Politics of Pensions: A Comparative Analysis of Britain, Canada, and the United States, 1880-1940. Madison: University of Wisconsin Press.

Parsons, Craig. 2007. How to Map Arguments in Political Science. Oxford: Oxford University Press.

Pierson, Paul. 1994. Dismantling the Welfare State? Reagan, Thatcher and the Politics of Retrenchment. New York: Cambridge University Press.

Pierson, Paul, and R. Kent Weaver. 1993. "Imposing Losses in Pension Policy." In Do Institutions Matter? Government Capabilities in the United States and Abroad, edited by R. Kent Weaver and Bert A. Rockman. Washington, DC: The Brookings Institution. 110-150.

Prince, Michael J. 2014. "The Universal in the Social: Universalism, Universality, and Universalization in Canadian Political Culture and Public Policy." Canada Public Administration 57 (3): 344-361. Accessed on April 25, 2017. Available online at http://onlinelibrary.wiley.com/doi/10.1111/capa.12075/abstract

Prince, Michael J., and Kathy Teghstsoonian. 2008. "The Harper Government's Universal Child Care Plan: Paradoxical or Purposeful Social Policy.” In How Ottawa Spends 2007-2008, edited by Bruce Doern. Montreal/Kingston: McGill-Queen's University Press. 180-199.

Quadagno, Jill. 1994. The Color of Welfare: How Racism Undermined the War on Poverty. New York: Oxford University Press.

Rice, James, and Michael Prince. 2013. Changing Politics of Canadian Social Policy. Revised ed. Toronto: University of Toronto Press. 
Ross, Fiona. 2007. "Policy Histories and Partisan Leadership in Presidential Studies: The Case of Social Security." In The Polarized Presidency of George W. Bush, edited by George C. Edwards III and Desmond S. King. Oxford: Oxford University Press. 419-446.

Skocpol, Theda. 1990a. "Sustainable Social Policy: Fighting Poverty without Poverty Programs." The American Prospect 2: 58-70.

----. _ _ 1990b. "Thinking Big: Can National Values or Class Factions Explain the Development of Social Provision in the United States? A Review Essay.” Journal of Policy History 2 (4): 425-438.

1992. Protecting Soldiers and Mothers: The Political Origins of Social Policy in the United States. Cambridge, Massachusetts: The Belknap Press of the Harvard University Press.

Steensland, Brian. 2008. The Failed Welfare Revolution: America's Struggle over Guaranteed Income Policy. Princeton: Princeton University Press.

Steinmo, Sven, and John Watts. 1995. "It's the Institutions, Stupid! Why Comprehensive National Health Insurance Always Fails in America." Journal of Health Politics Policy and Law 20 (2): 329-372. Accessed on April 25, 2017. Available online at http://www.svensteinmo.com/articles/Steinmo_Watts_1995_its_the_institutions_stupid.p df

Teles, Stephen. 1996. Whose Welfare: AFDC and Elite Politics. Lawrence: University of Kansas Press.

Théret, Bruno. 2002. Protection sociale et fédéralisme dans le miroir de l'Amérique du Nord. [Social Protection and Federalism in the Mirror of North America]. Brussels-Montreal: Peter Lang/Presses de l'Université de Montréal.

. 2013. "Annual Statistical Supplement to the Social Security Bulletin, 2012." Accessed on December 17, 2016. Available online at http://www.ssa.gov/policy/docs/statcomps/supplement/2012/supplement12.pdf

Van de Water, Paul, and Arloc Sherman. 2012. Social Security Keeps 21 Million Americans Out of Poverty: A State-by-State Analysis. Washington, DC: Center of Budget and Policy Priorities. Accessed on December 17, 2016. Available online at http://www.cbpp.org/files/10-16-12ss.pdf

Waddan, Alex. 2003. "Redesigning the Welfare Contract in Theory and Practice: Just What is Going on in the USA." Journal of Social Policy 32 (1): 19-35.

Weaver, R. Kent. 2000. Ending Welfare as We Know It. Washington, DC: Brookings Institution Press.

Webster, Charles. 2002. National Health Service: A Political History. Revised ed. Oxford: Oxford University Press.

Wiseman, Michael and Martynas Yčas. 2008. "The Canadian Safety Net for the Elderly," Social Security Bulletin, 68(2): 53-67. Available online at www.ssa.gov/policy/docs/ssb/v68n2/v68n2p53.pdf 
